Proc. Estonian Acad. Sci. Eng., 2002, 8, 4, 276-285

\title{
Influence of wind speed gusts on power generation
}

\author{
Teolan Tomson and Maire Hansen
}

Estonian Energy Research Institute at Tallinn Technical University, Paldiski mnt. 1, 10137 Tallinn, Estonia; teolan@anet.ee

Received 4 January 2002, in revised form 27 March 2002

\begin{abstract}
Based on the analysis of the Estonian offshore and onshore wind database, the boundaries of the probability of wind speed gusts and lulls, which lead to disturbances in the electrical grid, are assessed. These boundaries are assigned to the probability distribution function (pdf) of wind speed gusts and lulls on one hand and to the pdf of power deflections on the other. The probability of electrical disturbances remains between these boundaries. For the evaluation of the pdf of gusts and lulls, standard deviation of the wind speed can be used.
\end{abstract}

Key words: wind speed gust (lull), wind power gust (lull), disturbances in the electrical grid.

\section{INTRODUCTION}

In scientific publications the wind speed gusts are mainly analysed from the point of view of the fatigue and maximum load $\left[{ }^{1-3}\right]$. However, they are essential also from the point of view of power generation since they may cause disturbances (voltage flicker) in the electrical grid. Due to the stochastic character of the wind speed (an example is given in Fig. 1), statistical methods are to be used by tackling this problem.

A gust influences the electrical grid if wind speed $u$ changes in such a way that it brings along changes in the wind turbine generator (WTG) output power (wind power) $P_{\mathrm{G}}^{*}$ and the speed variation lasts sufficiently long for the WTG to react (depending on its mechanical inertia and characteristics of the controller). A shortduration gust (or lull, which is a "negative gust") does not influence the grid since WTG acts as a low-pass filter with a boundary frequency of about $0.3 \mathrm{~Hz}$.

Figure 1 shows that in this case maximum power gusts occur near 6:00 AM when wind speed $u$ lies in the range of $8-11 \mathrm{~m} \mathrm{~s}^{-1}$. An opposite situation appears after 8:00 AM when in spite of significant wind speed gusts, wind power gust has zero value. The reason is that wind speed exceeds the WTG stabilization speed $u>u_{\text {stabil }}=12 \mathrm{~m} \mathrm{~s}^{-1}$. 


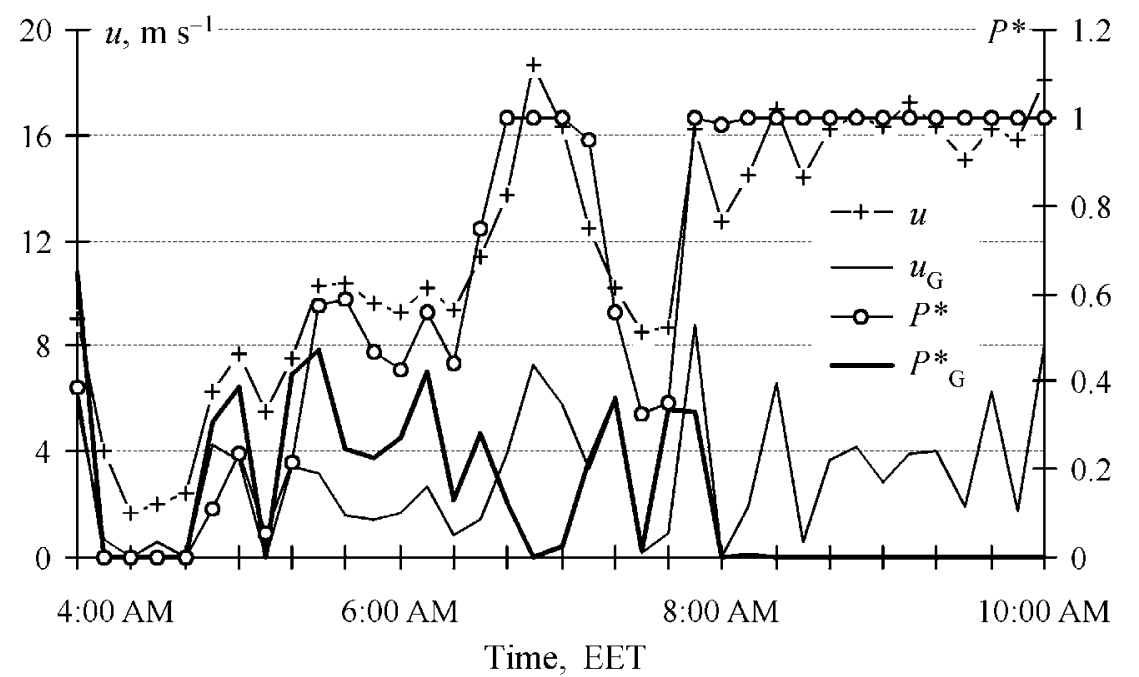

Fig. 1. Diagram of the wind speed $u$, wind speed gusts $u_{\mathrm{G}}$, power $P^{*}$ (in relative units) and power gusts $P_{\mathrm{G}}^{*}$ at the Harilaid site (in NW of Estonia), 5 October, 1997.

Modern anemometers can measure wind speed with the sampling interval of $1 \mathrm{~s}$. This value can be considered as the minimum gust duration. The WTG output power diagrams $\left[{ }^{4}\right]$ demonstrate that such short gusts are smoothed by WTG, acting as a low pass filter. Still shorter gusts may be observed as maximum values of the wind speed but they do not disturb the grid. The change in the average value of the wind speed within a data recording interval of $10 \mathrm{~min}$ (a normal filing interval for the most of contemporary data loggers) will certainly bring along a power output variation (provided WTG has no fast controller) and can be considered as an extended gust. Therefore $10 \mathrm{~min}$ can be considered as the maximum gust duration.

The data on the gusts recorded by the Estonian Meteorological and Hydrological Institute are the maximum values of the wind speed within a sampling interval of three hours and cannot be used in this analysis.

\section{IMPACT OF THE VARIATION OF THE WIND SPEED ON THE ELECTRICAL GRID}

Wind power is a non-linear function of the wind speed. Relative to the average value of the wind speed, a significant wind speed gust in the range $u>u_{\text {stabil }}$ (Fig. 2) has no impact on the WTG output capacity. In the range $u<u_{\text {stabil }}$ even a modest gust may bring along an essential disturbance of the WTG output capacity. Figure 2 explains this phenomenon for a lull.

The WTG output power changes due to a gust, if one of the following situations occurs. 


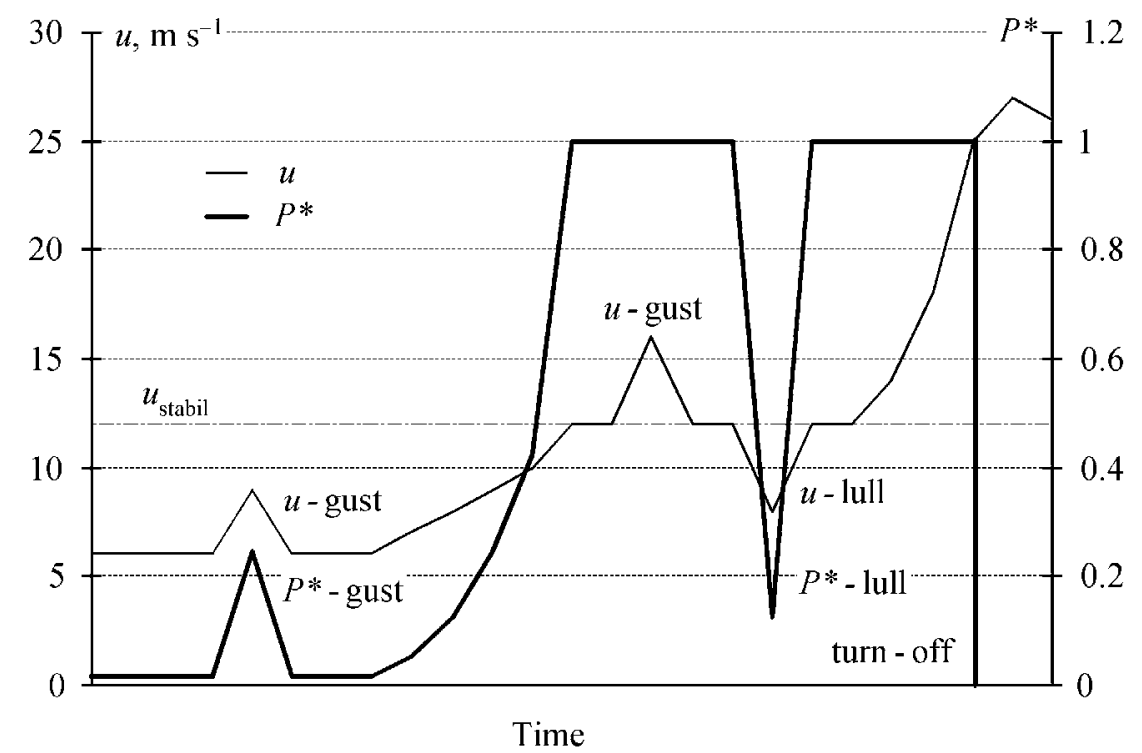

Fig. 2. Wind speed gusts and lulls, transformed to the WTG relative output capacity $P^{*}$ gusts and lulls.

1. The average wind speed exceeds the WTG safety threshold (mostly $25 \mathrm{~m} \mathrm{~s}^{-1}$ ). The (extended) gust amplitude has no significance in this case. For instance, a gust with the amplitude of $6 \mathrm{~m} \mathrm{~s}^{-1}$ by the average speed of $20 \mathrm{~m} \mathrm{~s}^{-1}$ shows the same results as a gust with the amplitude of $2 \mathrm{~m} \mathrm{~s}^{-1}$, but by the average speed of $24 \mathrm{~m} \mathrm{~s}^{-1}$. Both of them induce turn-off of the WTG, with a $100 \%$ change of output capacity. Under conditions prevailing in Estonia, the average wind speed $\left(25 \mathrm{~m} \mathrm{~s}^{-1}\right)$ has been exceeded only in a few cases and therefore this range will be ignored below.

2. The wind speed varies in the range of $4<u<13 \mathrm{~m} \mathrm{~s}^{-1}$, or even $8<u<13 \mathrm{~m} \mathrm{~s}^{-1}$. For modern WTGs, in this range the wind speed variation of $\Delta u=5 \mathrm{~m} \mathrm{~s}^{-1}\left[{ }^{2}\right]$ is the most decisive, since then the WTG output capacity will vary for $73 \%$. From the point of view of electrical disturbances it has no significance whether a gust or lull creates disturbance in the grid's performance. In this range it is not expedient to assess the wind speed gusts (lulls) alone, but to assess also the wind power gusts (calculated with the WTG inertia excluded). This method avoids the problem of specifying the initial average value of the wind speed.

\section{THE WTG POWER CURVE USED IN THE ANALYSIS}

In Fig. 3, the averaged power curves of modern big WTGs with the capacity of 1-2.5 MW are shown (based on the information obtained from the companies Bonus, DeWind, NegMicon, Nordex, and Vestas). The approximating equation for the relative power $P^{*}=P / P_{\text {rated }}$ is the following: 


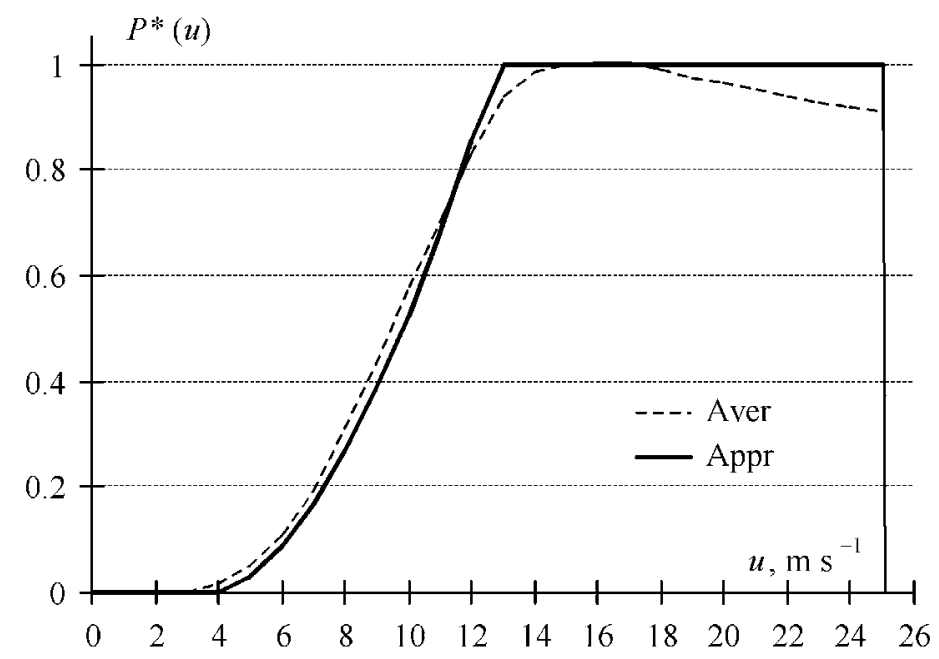

Fig. 3. The average $P^{*}(u)$ characteristic of big European WTGs and the used approximation.

if $u<3.75 \mathrm{~m} \mathrm{~s}^{-1}$, then $P^{*}=0$,

if $3.75<u<13 \mathrm{~m} \mathrm{~s}^{-1}$, then $P^{*}=(u-3.75)^{1.75} / 47$,

if $u>13 \mathrm{~m} \mathrm{~s}^{-1}$, then $P^{*}=1$.

Here $P_{\text {rated }}$ is nominal power.

\section{GUSTS AND LULLS OF THE WIND SPEED AND WIND POWER}

The wind speed gusts are usually characterized by the gust factor $\left[{ }^{1}\right]$, which is the ratio of the maximum speed $u_{\max }$ and the average value of $u$ in a certain sampling interval $n$. The gust amplitude is usually defined as a difference of the maximum speed and its average value in a certain sampling interval $\left[{ }^{2}\right]$. We shall define the gust in a recording interval $n$ via its preceding $(n-1)$ and following $(n+1)$ intervals, considering that the duration of a gust does not exceed the length of the sampling interval.

A wind speed gust is

$$
u_{\mathrm{G}}=u_{\max , n}-\left(u_{n-1}+u_{n+1}\right) / 2,
$$

that is the difference between the wind speed maximum within the $n$th recording interval and the average value of the preceding and the following intervals. Usage of "own" sampling interval is hardly suitable as the duration of the gust $T$ will influence the average value and in this way its amplitude $u_{\mathrm{G}}=f(T)$ as well.

Difference of the average wind speed in the $n$th sampling interval from the average of the preceding and following intervals is defined as the amplitude of an extended gust 


$$
U_{\mathrm{G}}=u_{n}-\left(u_{n-1}+u_{n+1}\right) / 2,
$$

A gust is also an event, which may cause a WTG power output disturbance (depending on its unknown duration $T$ ), but extended gust is an event which certainly causes a WTG power output disturbance (provided no controller correction is made). The wind speed lulls $u_{\mathrm{L}}$ and extended lulls $U_{\mathrm{L}}$ can be defined in a similar way.

Since to each wind speed value corresponds a certain WTG (relative) output power, in a similar way we can define the amplitude of wind power gusts $P_{\mathrm{G}}^{*}$ and lulls $P_{\mathrm{L}}^{*}$; for example

$$
P_{\mathrm{G}}^{*}=P^{*}\left(u_{\max , n}\right)-\left(P^{*}\left(u_{n-1}\right)+P^{*}\left(u_{n+1}\right)\right) / 2,
$$

which both assess possible disturbances of the grid in the sampling interval $n$. We can define the extended wind power gusts and lulls together as power deflection

$$
P_{\mathrm{D}}^{*}=\left|P^{*}\left(u_{n}\right)-\left(P^{*}\left(u_{n-1}\right)+P^{*}\left(u_{n+1}\right)\right) / 2\right| \text {. }
$$

Here we have ignored the sign of the power deflection as there are no definite maximum or minimum values.

If the disturbances caused by wind speed gusts and lulls have to be calculated, we must find: 1) the pdf of the amplitude of wind power gusts and lulls $f\left(P_{\mathrm{G}}^{*}, P_{\mathrm{L}}^{*}\right)$, and 2) the pdf of the duration of wind power gusts $f_{\mathrm{TG}}(T>\tau)$ and lulls $f_{\mathrm{TL}}(T>\tau)$, where $\tau$ is the transition time of the WTG.

The probability of an electrical disturbance $f\left(P_{\mathrm{E}}^{*}\right)$ can be written as

$$
f\left(P_{\mathrm{E}}^{*}\right)=f_{\mathrm{TG}}(T>\tau) \cdot f_{p}\left(P_{\mathrm{G}}^{*}\right)+f_{\mathrm{TL}}(T>\tau) \cdot f_{p}\left(P_{\mathrm{L}}^{*}\right) .
$$

The boundary condition $f\left(P_{\mathrm{E}}^{*}\right)=f\left(P_{\mathrm{D}}^{*}\right)$ means that the probability of extended power deflections is the lower margin for electrical grid disturbances.

In the present work we shall study the behaviour of $f\left(P_{\mathrm{G}}^{*}\right), f\left(P_{\mathrm{L}}^{*}\right)$, and $f\left(P_{\mathrm{D}}^{*}\right)$ in the Estonian shelf sea and on the coast. The assessment of the duration probability of wind speed gusts (and lulls) $f(T>\tau)$ is a complicated problem and will be treated elsewhere.

\section{THE USED DATABASE}

Harilaid (HRL), which is a small and level islet $\left(23^{\circ} 2.7^{\prime} \mathrm{E} ; 58^{\circ} 56.4^{\prime} \mathrm{N}\right)$ between Hiiumaa and Vormsi islands, is used as an offshore site. Measurements (23193 samplings) have been made at the heights of 20,35 , and $50 \mathrm{~m}$ within the time interval from 21.09.97 to 02.03.98. These data do characterize offshore wind conditions $\left[{ }^{5,6}\right]$.

Uulurand (ULR) measurement site is located in the Gulf of Pärnu $\left(24^{\circ} 5^{\prime} \mathrm{E}\right.$; $\left.58^{\circ} 17.2^{\prime} \mathrm{N}\right)$, about $0.5 \mathrm{~km}$ away from the waterline in a low-level $(10-15 \mathrm{~m})$ pine forest. Measurements (27694 samplings) have been made at the heights of 26 and 
$44 \mathrm{~m}$ within the time interval from 17.09.00 to 03.10 .01 , but the data basis is not continuous. These data characterize onshore wind conditions as being close to the conditions in an onshore wind park.

The functional relations presented below are valid for wind power gusts $P_{\mathrm{G}}^{*}$, lulls $P_{\mathrm{L}}^{*}$, and deflections $P_{\mathrm{D}}^{*}$, if not mentioned otherwise.

\subsection{Harilaid}

The probability distributions of gusts $f\left(P_{\mathrm{G}}^{*}\right)$ and lulls $f\left(P_{\mathrm{L}}^{*}\right)$ practically coincide (Fig. 4) and can be presented with a single distribution curve $f\left(P_{\mathrm{G}}^{*}, P_{\mathrm{L}}^{*}\right)$. At the height of $50 \mathrm{~m}$ these distributions are close to the exponential one, because they are represented by straight lines in a linear-logarithmic scale. Figure 5

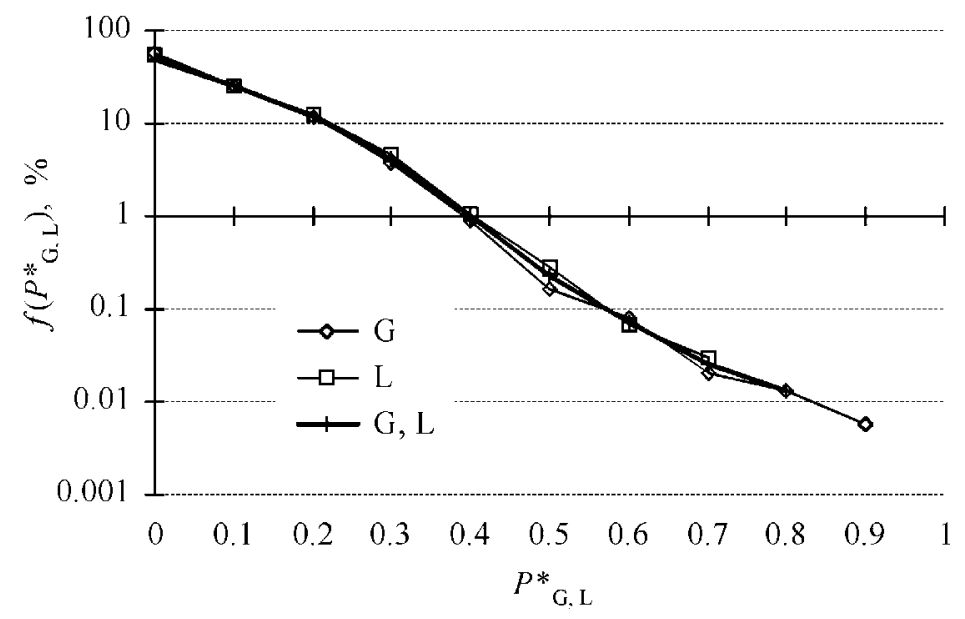

Fig. 4. Probability of power gusts (G) and lulls (L) at Harilaid at the height of $50 \mathrm{~m}$.

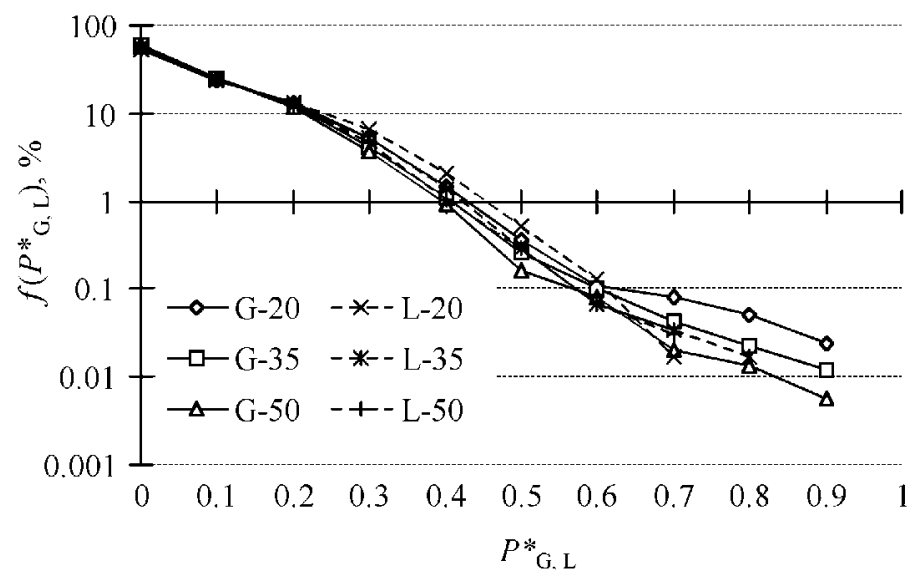

Fig. 5. Probability of gusts (G) and lulls (L) at Harilaid for the heights of 20, 35, and $50 \mathrm{~m}$. 


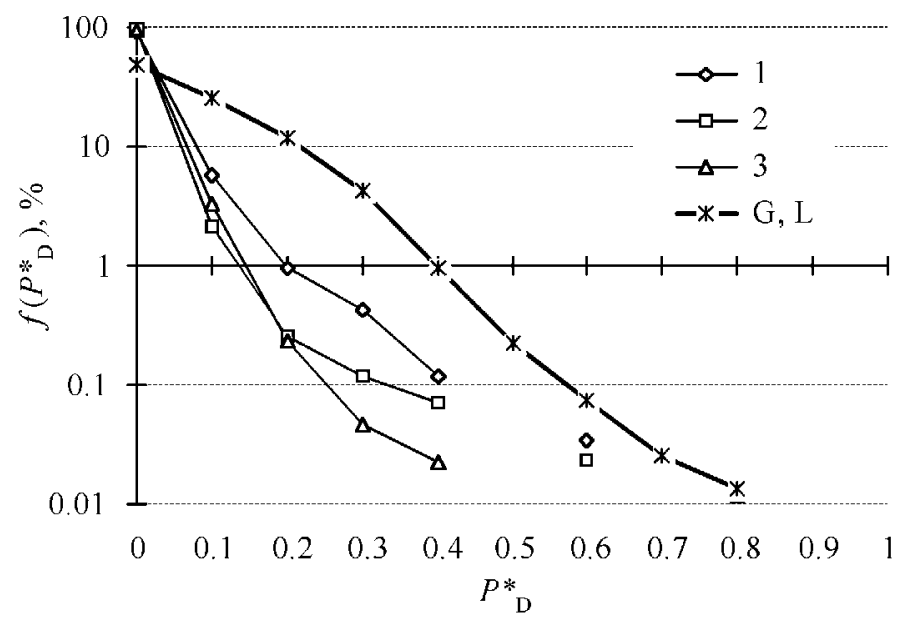

Fig. 6. Dependence of the probability of the extended power deviation $P_{\mathrm{D}}^{*}$ in the seasons $1-3$ at Harilaid (at $50 \mathrm{~m}$ ).

demonstrates that they depend neither on the height nor season (the seasons correspond to different databases with different average wind speeds of 8.55 , 7.73 , and $9.77 \mathrm{~m} \mathrm{~s}^{-1}$ ). The distribution of power deflection depends on seasons, probably owing to different average values of the wind speed (Fig. 6; notice that frequency of electrical disturbances is twice higher than that caused by gusts or lulls). The area between the curve $f\left(P_{\mathrm{GL}}^{*}\right)$ and the curves 1-3 (presenting $f\left(P_{\mathrm{D}}^{*}\right)$ in different seasons) is the probability area for electrical disturbances in the grid. The curve " 3 " is the most reliable as the number of events with $P_{\mathrm{D}}^{*}>0.2$ in seasons 1 and 2 is low.

\subsection{Uulurand}

At this site the probability distribution functions for wind power gusts $f\left(P_{\mathrm{G}}^{*}\right)$ and lulls $f\left(P_{\mathrm{L}}^{*}\right)$ are different (Fig. 7). They are also close to the exponential distribution for the heights of 26 and $44 \mathrm{~m}$. The distributions of wind power gusts $f\left(P_{\mathrm{G}}^{*}\right)$ do not depend essentially on the height. It is difficult to state anything definite about lulls as the number of events with average wind speed over $12 \mathrm{~m} \mathrm{~s}^{-1}$ is small, and that of lulls under these conditions is even smaller. This feature results from the low average value of the wind speed at $44 \mathrm{~m}\left(5.11 \mathrm{~m} \mathrm{~s}^{-1}\right)$ and $26 \mathrm{~m}\left(4.91 \mathrm{~m} \mathrm{~s}^{-1}\right)$. Therefore the distributions $f\left(P_{\mathrm{L}}^{*}\right)$ at 44 and $26 \mathrm{~m}$ cannot be considered reliable for the "high" values of power lulls $P_{\mathrm{L}}^{*}>0.3$. On the graphics, observed data with low number of events are not connected with a curve, as they cannot be considered reliable. The difference between $f\left(P_{\mathrm{L}}^{*}\right)$ and $f\left(P_{\mathrm{G}}^{*}\right)$ can be found for the "low" values of $P_{\mathrm{L}}^{*}<0.3$ when the number of events is sufficient. Thus, we can expect different wind structure at the offshore and onshore sites. 


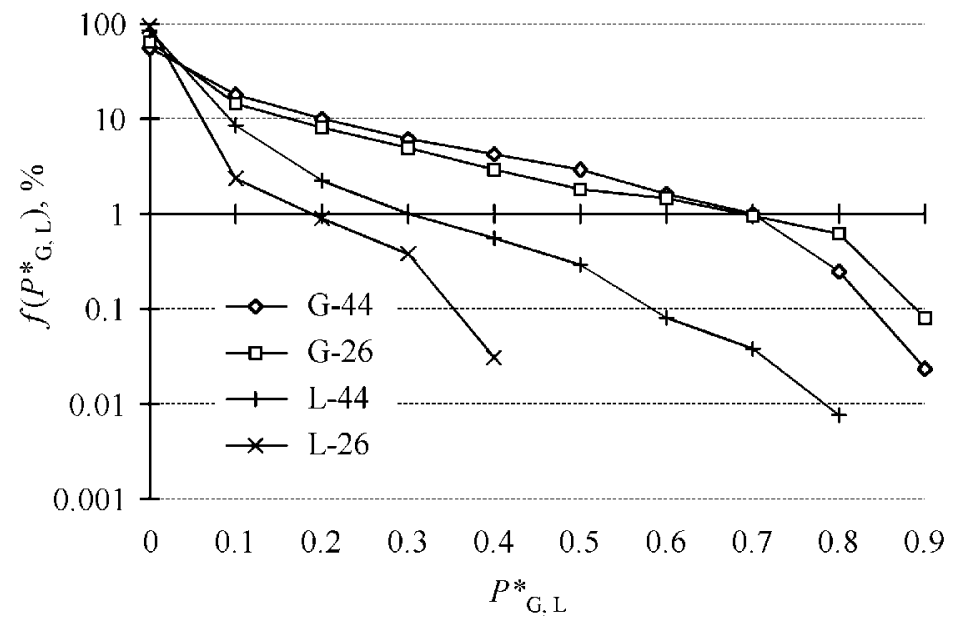

Fig. 7. Probability distribution functions of gusts $(\mathrm{G})$ and lulls $(\mathrm{L})$ at the Uulurand site for different heights.

\section{COMPARISON OF WIND CHARACTERISTICS AT HARILAID AND UULURAND}

In Fig. 8, the wind power gusts and lulls at Harilaid at the height of $50 \mathrm{~m}$ and Uulurand at the height of $44 \mathrm{~m}$ as well as the power deflections $f_{P}\left(P_{\mathrm{D}-50}^{*}\right)$ and $f_{P}\left(P_{\mathrm{D}-44}^{*}\right)$ are compared to demonstrate their essential difference. We can see that the area of possible electrical disturbances in the grid is narrower in offshore

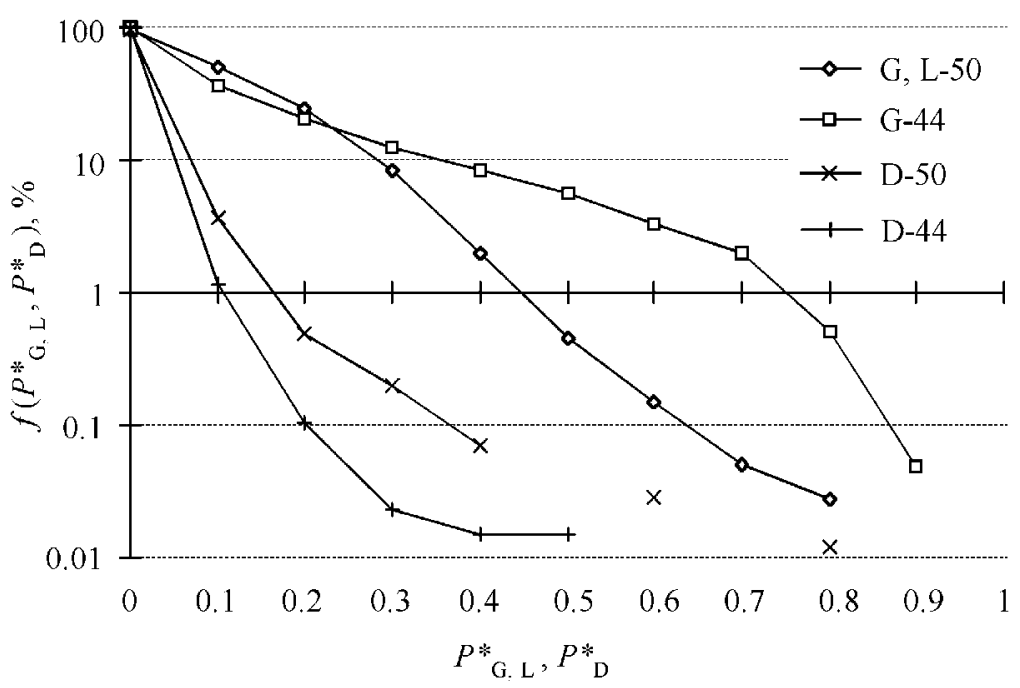

Fig. 8. Comparison of the characteristics of gusts at Harilaid and Uulurand. 
conditions (the area between curves G, L-50 and D-50 is narrower). It means that offshore wind farms can probably provide electrical energy of better quality, evidently due to smaller turbulence on the sea than at the coast where eddies seem to be smaller and more frequent.

\section{RELATION OF GUSTS TO THE STANDARD WIND DEVIATION}

Not all wind monitors record the maximum and minimum wind speeds for each sampling interval. For instance, wind monitors of the NRG-Systems company (USA), widely used in preparatory measurements for designing wind parks, record the average value $u$ and its standard deviation $\sigma(u)$ for each sampling interval only. The maximum and minimum values are stored once per day. Therefore the correlation between the measured standard deviation $\sigma$ and corresponding power gusts and lulls is of interest. In Fig. 9 these quantities are presented for the Harilaid site for the height of $50 \mathrm{~m}$. Especially for small deviations $\left(\sigma<1 \mathrm{~m} \mathrm{~s}^{-1}\right)$ the correlation is high, and evidently it is possible to estimate grid disturbances based on the standard deviations of measured wind speed. Future investigations in this field are necessary to finally validate this conclusion.

\section{CONCLUSIONS}

1. The boundaries of probabilities for wind power gusts and lulls in the offshore and onshore wind conditions in Estonia, which lead to grid disturbances, are assessed. The boundaries are defined as pdf of power gusts and lulls on one

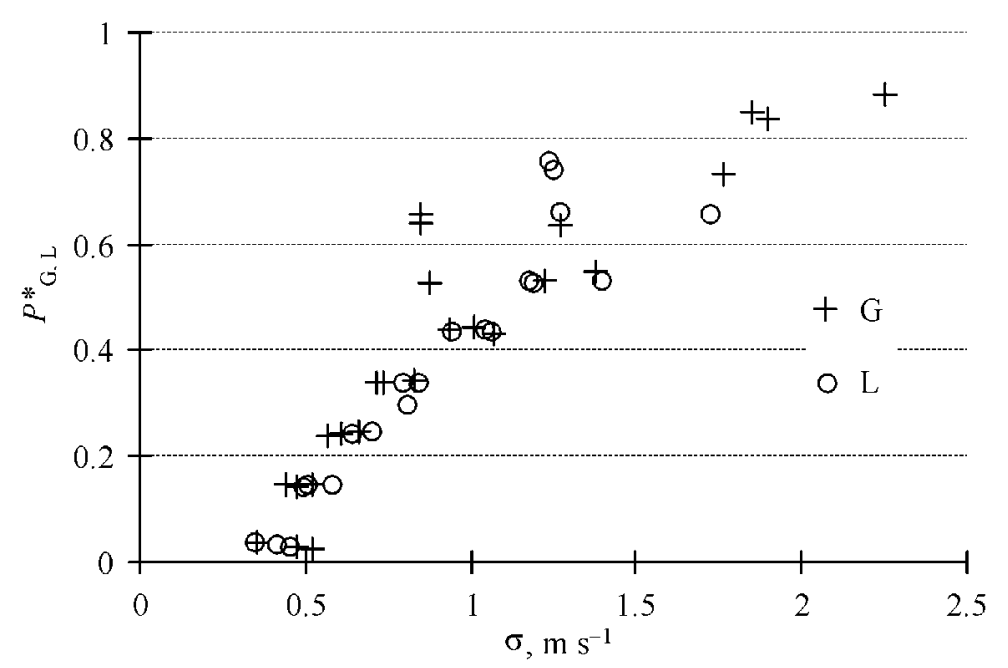

Fig. 9. The gusts and lulls of WTG output power are well correlated with the wind velocity standard deviation. 
hand and as the pdf of power deflections on the other hand. The probability of electrical disturbances remains within the described range, but cannot be calculated at the existing level of knowledge.

2. All the probability distributions are close to the exponential distribution.

3. In offshore conditions the probability distributions of gusts and lulls coincide and do not depend on the measurement height.

4. In onshore conditions the probability distribution of gusts does not depend on the height while that of lulls does due to low value of wind speed at lower heights.

5. Practically linear dependence exists between the probability of gusts (and lulls) and the standard deviation of the wind speed, in particular for small values of the standard deviation.

6. Offshore wind parks can probably generate electricity of higher quality in comparison with the onshore wind parks.

\section{REFERENCES}

1. Burton, T., Sharpe, D., Jenkins, N., and Bossany, E. Wind Energy Handbook. J. Wiley, Chichester-Toronto, 2001.

2. Larsen, G. Chr. and Hansen, K. S. Statistics of offshore wind speed gusts. In Proc. European Wind Energy Conference. Copenhagen, 2001, 753-756.

3. Mann, J. Extreme gusts over coastal waters. In Proc. European Wind Energy Conference. Copenhagen, 2001, 665-668.

4. Heier, S. Windkraftanlagen im Netzbetrieb. B.G. Teubner, Stuttgart, 1995.

5. Tomson, T. and Hansen, M. Wind dynamics in the Moonsund Arhipelago. Proc. Estonian Acad. Sci. Eng., 2000, 6, 61-69.

6. Tomson, T. Periodical component of the West Estonian wind. Proc. Estonian Acad. Sci. Eng., 2001, 7, 50-57.

\section{Tuule kiiruse puhangute mõju tuuleenergia genereerimisele}

\section{Teolan Tomson ja Maire Hansen}

Mere- ja rannapealsete tuulemõõtmiste andmetest lähtuvalt on leitud elektrivõrku häirivate tuule kiiruse puhangute ja vaibete statistilised rajad. Ülalt on rajaks tuule kiiruse puhangute ja vaibete sagedusjaotus, alt võimsushälvete sagedusjaotus. Tegelike elektriliste häirete tõenäosus jääb nende rajade vahele, kuid tänaste teadmiste juures pole see täpsemalt määratav ja siinses töös on leitud vaid elektriliste häirete esinemispiirkond. On selgitatud, et (tavaliselt igas mõõteseadmes registreeritava) tuule kiiruse standardhälbe ja võimsushälvete vahel eksisteerib tihe korrelatiivne seos, mida saab kasutada edasistes võrguhäirete uurimistes. Merepealsed tuulegeneraatorid tagavad tõenäoliselt elektri parema kvaliteedi, kuna häirete esinemispiirkond jääb kitsamaks võrreldes rannapealsetega. 